\title{
Does Fiscal Policy Stance Affect Public Expenditure: Evidence from Kenya
}

James M. Gatauwa ${ }^{1}$

\section{ARTICLE INFO}

Submitted : 05.05.2020

Revised : 07.10.2020

Accepted : 10.12.2020

Available : 29.12.2020

iThenticate similarity

score: $18 \%$

JEL classification:

E60, E62, H50

Keywords:

Fiscal Policy Stance,

Economic Growth, Macroeconomic

Factors,

Public Expenditure

\begin{abstract}
A B S T R A C T
The purpose of this paper is to examine the effect of fiscal policy stance on public expenditure in Kenya while underpinned by the theory of fiscal policy, Peacock-Wiseman hypothesis, and Wagner's Law of increasing state activities. The methodology used was time series modelling involving the following steps; firstly, employing descriptive statistic analysis. Secondly, diagnostic testing involving stationarity test, cointegration test, and Granger causality tests. Thirdly, time series modelling was done using VECM and VAR models. Finally, post-diagnostic tests involving serial correlation test and heteroscedasticity test. The research indicates a negative relationship between fiscal policy stance (a budget deficit) and public expenditure, but fiscal stance through tax has a positive relationship with public expenditure. Fiscal policy stance and public expenditure are cointegrated, as shown by the Johansen cointegration test. Still, there is no short run causality between them as indicated by the Wald test statistics. The study is limited to fiscal policy stance and public expenditure in Kenya while considering selected macroeconomic factors. The research findings are vital to policymakers. Fiscal policy stance indirectly affects public expenditure through economic growth and macroeconomic factors. This implies that fiscal policy stance does not substantially affect public expenditure as supported by the theory of fiscal policy that contends that policymakers could have a lower incentive to pursue public interests compared to their interests.
\end{abstract}

Cite this article as: Gatauwa, J. M. (2020). “Does Fiscal Policy Stance affect Public Expenditure: Evidence from Kenya", International Journal of Public Finance, 5(2), 295-310.

\footnotetext{
${ }^{1}$ Dr. in Finance, Department of Accounting and Finance, Kenyatta University, Kenya, ORCID: 0000-00022804-5070,jmgatauwa@gmail.com
} 


\section{Introduction}

There have been increasing concerns on the level of public expenditure by governments, especially in African economies. Yet, there are limited public resources available to meet the various social and economic welfare needs of citizens of a nation or economy. There is a growing trend of enacting fiscal rules across countries to have a balanced budget (Tsai, 2014) and avoid possible cases of unsustainable public expenditure levels (Bui, 2020) or high public debt amounts, which can lead to a crisis. That has elicited interest in how best governments can control public expenditure in the wake of limited public revenue sources and a growing population that is more enlightened on the various public needs that governments need to fulfill. In order to control the level of public expenditure, governments are expected to use fiscal policy in allocating and redistributing public resources while considering the macroeconomic environment prevailing in an economy. Hence, this paper seeks to respond to the question of whether fiscal policy stance affects the levels of public expenditure in a country. That would be attained by examining the relationship between fiscal policy stance, economic growth, macroeconomic factors, and public expenditure in Kenya. There is no single study in the empirical literature that has integrated these variables into one study. Furthermore, Kenya is among the nations that have been grappling with the question of prudent utilization of public resources hence the justification of researching in the Kenyan context.

Fiscal policy is a tool that governments use to control the level of public expenditure (Tanzi, 2006; Perotti, 2007) since fiscal policy aims to redistribute and reallocate economic resources while enhancing stabilization in an economy. Fiscal policy stance is the fiscal position taken by a government, and it can either be contractionary/tight or expansionary/loose. The contractionary outlook is when there is an increasing fiscal surplus or a decreasing fiscal deficit over a time period. The expansionary fiscal stance is when the fiscal balance is in deficit. The deficit level is increasing, or the surplus's extent decreases compared to other periods (Pailwar, 2008). Economic growth refers to the level of gross domestic product (GDP) growth in an economy or country.

In contrast, macroeconomic factors are the economic indicators of the economic behaviour and policies that affect an economy (Dornbusch et al., 2017). Public expenditure refers to government expenditure on various activities such as spending on infrastructure development, wages, salaries, interest on public debt, utility bills, etc. Public expenditure can be categorized into either recurrent expenditure or development expenditure (Barro \& Grilli, 1994; Njeru, 2003; Dornbusch et al., 2017).

There is insufficient evidence on the relationship between fiscal policy stance, economic growth, macroeconomic factors, and public expenditure from the existing finance literature. Therefore this paper aims to examine the relationship between the study variables above in the Kenyan context. This paper is subsequently divided into 
the following sections; literature review, research methodology, data analysis, and conclusion.

\section{Literature Review}

\subsection{Theoretical Review}

This paper is underpinned by three theories: the theory of fiscal policy, the Peacock-Wiseman hypothesis, and Wagner's law of increasing state activities. As asserted by Musgrave (1959) and Johansen (1965), the theory of fiscal policy states that the goals of fiscal policy extend beyond stabilization since fiscal tools can also be used for redistributing income and for reallocating resources. Tanzi (2006) argues that policymakers have an obligation to promote the citizens of a nation's social welfare. Therefore, this theory asserts that fiscal policy can influence the increase or decrease in public spending, depending on the priorities at hand. However, the theory of fiscal policy has underlying imperfections. First, there is scepticism that policymakers can be separated from their interests and incentives to pursue the public interest. Secondly, the theory has higher validity if better institutional arrangements are in place (Tanzi, 2006). Hence, this theory underpins the link between fiscal stance and public expenditure since fiscal policy aims to redistribute and reallocate resources in a country.

The Peacock-Wiseman hypothesis states that public expenditure increases in a step-like manner, unlike the smooth and continuous pattern. Peacock and Wiseman (1961) gave a displacement hypothesis that explains a temporary rise in government spending versus GDP in the United Kingdom (UK) from 1890 to 1955. The hypothesis stated that public expenditure in the UK did have a smooth pattern but seemed to surge up at distinct durations, especially steep peaks during war then steady patterns afterward. The trends are connected to the fact that public expenditure relies mainly on tax revenues, and the public's tolerable tax burden is stable unless there is an unusual disturbance. Thus, the Peacock-Wiseman hypothesis underpins the link between fiscal stance and public expenditure. Public expenditure is influenced by tax revenues, as explained by the fiscal surplus or fiscal deficit.

Wagner's law states that there is a tendency for public expenditure growth relative to national income in the long run. Wagner (1863) based on the German economy's law and noted that all types of governments demonstrated increasing public expenditure regardless of their sizes or intentions. However, Musgrave (1959) argued that Wagner's Law focused on the size of the public sector in the entire economy irrespective of total expenditure contents. Wagner's contribution to public expenditure theory is fundamental when we consider that before Wagner made these observations, the prevailing notion was that government activities would tend to decline as a country grows more prosperous (Henrekson, 1993). In conclusion, Wagner's Law supports the link between economic growth and macroeconomic factors, even though it is implicitly and public expenditure. 


\subsection{Empirical Review}

This paper argues that there is a relationship between fiscal policy stance and public expenditure, consistent with Stancik \& Valila (2012) and Tanzi (2006). Furthermore, the theory of fiscal policy asserts that fiscal policy aims to redistribute and reallocate resources in the various sectors of an economy. Therefore, the theoretical underpinning of the relationship between fiscal policy stance and public expenditure holds. Fiscal stance indicators are tax and budget deficits, which are measures also used by Gatauwa et al. (2017), Amanja \& Morrissey (2005), and Clark \& Dilnot (2001). Economic growth as measured by GDP growth and macroeconomic factors (inflation rate, unemployment rate, and foreign aid \& grants). There are several macroeconomic factors, but this paper has focussed on inflation, unemployment, and foreign aid and grants since the other macroeconomic factors have extensively been studied in cross-country studies. Public expenditure is the dependent variable in this paper, and it is measured by recurrent and development expenditure. However, the general proposition is that economic growth and macroeconomic factors mediate the relation between fiscal policy and public expenditure.

On the influence of economic growth in the relationship between fiscal policy stance and public expenditure, the fiscal policy theory asserts that fiscal policy aims to ultimately stabilize an economy, which underpins the relationship between fiscal policy and economic growth. Wagner's law and Peacock-Wiseman hypothesis state that economic growth and public expenditure have a positive relationship since public expenditure tends to grow as an economy expands. There are several empirical studies conducted on fiscal policy, economic growth, and public expenditure. For instance, there are studies conducted on fiscal policy and economic development (Temple, 2003; Amanja \& Morrissey, 2005; Glomm \& Rioja, 2006; Semmler et al. 2007; Perotti, 2007) and economic growth and public expenditure (Romer, 1990; Barro, 1991; Bagdigen \& Cetintas, 2003; Sakyi \& Adams, 2012; Srinivasan, 2013). However, these studies have varied findings, which also examine the variables inconclusively. Furthermore, there is no single study in the literature that has examined the combined effect of the fiscal stance, economic growth, macroeconomic factors, and public expenditure.

The empirical literature on public expenditure, as evidenced by studies conducted by Sans and Velazquez (2002) and Shonchoy (2010) in OECD countries and developing countries, respectively, indicate that there are factors or determinants of public expenditure. The findings show that political and institutional variables, size of the economy, population density, prices, and governance significantly affect expenditure. The key determinants seem to be similar to other studies done even though there are research methodological differences with Shonchoy (2010) using panel data models. Sans and Velazquez (2002) have adopted a three-stage least squares method. However, these studies have not examined the effect of macroeconomic factors such as inflation, unemployment, or foreign aid and grants on public expenditure. 
In the global context, several studies have investigated fiscal sustainability, fiscal institutional quality, and stabilization (Kim, 2019; Sabir \& Qamar, 2019; Bui, 2020). For instance, Kim (2019) sought to investigate fiscal autonomy (tax revenues) and stabilization (total expenditure volatility) in the US for the study period 2001 to 2013. The study findings indicate that fiscal autonomy is necessary for state governments to perform one of the three Musgravian roles, such as stabilization, reallocation, or redistribution. However, the study is not clear on whether macroeconomic factors mediate or moderate the relationship between fiscal autonomy and public expenditure. Similarly, Sabir and Qamar (2019) examined the impact of fiscal policy and institutional quality on 11 selected Asian countries' inclusive growth process from 1996 to 2017. The findings indicate that fiscal policy and institutions positively affect inclusive growth. On the other hand, Bui (2020) investigates fiscal sustainability for a panel of 22 developing Asian economies from 1999 to 2017, indicating that, on average, fiscal policy is not sustainable, implying the strengthening and adaptation of an appropriate fiscal consolidation framework.

In Kenya, the existing literature on public expenditure has mainly been the reports on public expenditure trends, statistical abstracts, economic surveys, and a few research articles. For instance, Muthui et al. (2013) investigated how public expenditure affects economic growth from 1964 to 2011 using the vector error correction model (VECM). The findings indicate that public expenditure on health, public order, security, and transport has a positive relationship with economic growth. However, public expenditure on education has a mixed relationship with economic growth. Njeru (2003) examined foreign aid and public expenditure in Kenya using a utility modelling approach where the findings demonstrate a positive and significant relationship between the proportion of public expenditure in GDP and the proportion of foreign aid. However, Kenya has been emerging as less reliant on foreign aid to support public expenditure.

Notably, some of the studies examining public expenditure have sought to test the effect of economic growth apart from other macroeconomic factors such as inflation, unemployment, and foreign aid and grants. Mosoti (2014) examined public expenditure growth in Kenya from 1980 to 2012 using ordinary least squares (OLS) modelling. The findings indicate that population and GDP positively affect public expenditure growth, while free primary education positively affects public expenditure growth. However, inflation and foreign aid have an insignificant effect on public expenditure growth. Even though the study did not test the effect of fiscal policy on public expenditure, the study concludes that fiscal policy should be undertaken carefully to ensure that public expenditure is managed sustainably. On the relationship between public expenditure and private investments, Njuru et al. (2014) examined the effect of government spending on private investment in Kenya. The study adopted a vector autoregressive (VAR) technique using time series data from 1963 to 2012. The results show that both recurrent and development expenditure enhance private investment. The study further concludes that there is a need for the government to reallocate funds towards projects that are valuable to the private sector. 
Some studies examine the interaction of public expenditure with other variables apart from macroeconomic factors. For instance, according to a research report by Bird and Kirira (2009) on government institutions and donor partners' role in enhancing public environmental expenditure, there should be a consolidation of budgeted amounts on public expenditure on the environment since it would improve more accountability and synergy. The study also recommends that donor partners play a role in that they should consider sector budget support instead of multi-donor basket funds and traditional project interventions. Nafula et al. (2004) also examined public expenditure accountability in Kenya using a descriptive research approach. The study found that Kenya was faced with numerous challenges of wastage of resources, mainly due to weak procurement procedures, corruption, and inadequate monitoring systems. Hence, that justified the need for public expenditure tracking surveys.

\section{Research Methodology}

The causal research design was adopted since it helped establish the cause and effect of the relationship between fiscal policy stance, economic growth, macroeconomic factors, and public expenditure in Kenya. Zikmund (2002) argues that causal research mainly aims at establishing the cause and effect relationships among variables. The study period was from 1964 to 2015, while the population is the Kenyan economy since it captured the universe of these variables. Secondary data on fiscal policy and public expenditure was collected from the Kenya National Bureau of Statistics (KNBS) economic surveys and statistical abstracts, World Bank development indicators reports, and annual budget estimates books. The data collected were analyzed using descriptive and inferential statistics where it involved measures of central tendency and measures of dispersion. Pre-diagnostic testing was then done to include stationarity tests, cointegration tests, Granger causality tests, and finally, time series modelling. Post-diagnostic tests were done, such as autocorrelation tests and heteroscedasticity tests. The time series model used was the VECM, which enabled testing the relationship between fiscal policy stance and public expenditure. The model is as follows;

$Y_{t}=\beta_{0}+\beta_{1} Y_{t-1}+\sum_{i=1}^{m} \gamma_{i} X_{i t}+\varepsilon_{t}$

\section{Where:}

$\mathrm{Y}_{\mathrm{t}}=$ Dependent Variable; $\mathrm{Y}_{\mathrm{t}-1}=$ Lagged Dependent Variable ;

$\mathrm{X}_{\mathrm{it}}=$ Independent Variables

$\beta_{0}=$ The Constant; $\beta_{1}=$ Model Coefficient of the Lagged Dependent Variable;

$\gamma_{\mathrm{i}}=$ Model Coefficients of the Independent Variables; $\varepsilon_{\mathrm{t}}=$ Error Term 


\section{Data Analysis}

\subsection{Data Description}

Time series annual data was collected from KNBS reports and World Bank Development indicators reports. Data description highlights the annual trends on fiscal policy stance (budget deficit, tax) and public expenditure as indicated in Figures 1, 2, and 3, respectively, in the appendix. As shown in Figure 1 in the appendix, the annual budget deficits in Kenya seem to be constant from 1964 to 1990. However, in the 1990s, the deficit was volatile, implying that there were years with budget surpluses. Nevertheless, after the year 2000, the budget deficit has been on an increasing trend, suggesting an expansionary fiscal stance. As depicted by Figure 2 in the appendix, the annual tax revenue indicates an increasing trend over time but with slumps in the years 1995 and 2005. However, the rate of increase in the tax revenue is lower than that of public expenditure over the years, as seen in Figures 2 and 3 in the appendix, which concurs with the finding that the Kenya government has been using an expansionary fiscal stance to spur economic growth. Finally, public expenditure has an increasing smooth trend over the years as indicated in Figure 3 in the appendix, thus concurring with Wagner's Law of increasing state activities that public expenditure growth follows a smooth pattern instead of the step-like pattern argued by PeacockWiseman hypothesis.

\subsection{Summary Statistics}

The results in Table 1 sought to describe the data collected on the study variables using central tendency measures such as the mean, median, and standard deviation and measurements of dispersion such as the skewness and kurtosis. Fiscal policy stance, inflation rate, foreign aid, and public expenditure have a positive distribution as indicated by the skewness. On kurtosis, the variables are highly peaked relative to the peakedness of a normal distribution with values above three (3), implying that the distribution is leptokurtic.

Table 1: Summary Statistics of the Study Variables

\begin{tabular}{|l|l|l|l|l|l|l|l|}
\hline & $\begin{array}{l}\text { Budget } \\
\text { Deficit } \\
\text { Ksh. M }\end{array}$ & $\begin{array}{l}\text { Tax } \\
\text { Ksh. M }\end{array}$ & $\begin{array}{l}\text { Economic } \\
\text { Growth } \\
\text { (\%) }\end{array}$ & $\begin{array}{l}\text { Unemployment } \\
\text { Rate (\%) }\end{array}$ & $\begin{array}{l}\text { Inflation } \\
\text { Rate (\%) }\end{array}$ & $\begin{array}{l}\text { Foreign } \\
\text { Aid \& } \\
\text { Grants } \\
\text { Ksh. M }\end{array}$ & $\begin{array}{l}\text { Public } \\
\text { Expenditure } \\
\text { Ksh. M }\end{array}$ \\
\hline Mean & 42507.66 & 123379.8 & 4.17 & 9.51 & 9.95 & 6537.43 & 192760.3 \\
\hline Median & 395.50 & 30486.6 & 4.50 & 9.55 & 9.60 & 3875.64 & 53007.75 \\
\hline Maximum & 692000.0 & 1021597.0 & 14.50 & 12.20 & 28.80 & 57082.00 & 1953509.0 \\
\hline Minimum & -44986.00 & 735.32 & 0.20 & 6.90 & -0.50 & 3.42 & 1362.40 \\
\hline Std. Dev. & 100432.6 & 196962.8 & 2.69 & 1.08 & 6.13 & 10793.38 & 294372.1 \\
\hline Skewness & 2.14 & 1.95 & 0.92 & 0.15 & 1.01 & 2.82 & 1.96 \\
\hline Kurtosis & 6.24 & 5.84 & 5.53 & 3.83 & 4.35 & 12.18 & 6.13 \\
\hline $\begin{array}{l}\text { Jarque- } \\
\text { Bera }\end{array}$ & 59.90 & 48.39 & 20.47 & 1.61 & 12.31 & 241.87 & 52.44 \\
\hline
\end{tabular}

Source: Researcher's Computations 
Gatauwa, J. M. (2020). “Does Fiscal Policy Stance affect Public Expenditure: Evidence from Kenya", International Journal of Public Finance, 5(2), 295-310.

\subsection{Diagnostic Test Results}

This paper used the Augmented Dickey-Fuller (ADF) test for stationarity and the Johansen test for cointegration in undertaking diagnostic tests. The stationarity tests were undertaken on fiscal policy stance (tax, budget deficit), economic growth, unemployment rate, inflation rate, foreign aid and grants, and public expenditure in order to determine if they are stationary or not.

Table 2: Results of Stationarity Tests

\begin{tabular}{|l|l|l|l|}
\hline Variable & ADF Statistic at Level & $\begin{array}{l}\text { ADF Statistic at 1 } \\
\text { Differencing }\end{array}$ & $\begin{array}{l}\text { ADF Statistic at 2 }^{\text {nd }} \\
\text { Differencing }\end{array}$ \\
\hline Tax & $-0.5459(0.8728)$ & $-6.9760(0.0000)$ & \\
\hline Budget Deficit & $-0.2621(0.9223)$ & $-0.7274(0.8293)$ & $-10.7528(0.0000)$ \\
\hline Economic Growth & $-4.2361(0.0015)$ & & \\
\hline Unemployment Rate & $-3.8872(0.0042)$ & & \\
\hline Inflation Rate & $-5.5615(0.0000)$ & & \\
\hline Foreign Aid \& Grants & $1.1795(0.9975)$ & $-3.6062(0.0099)$ & $-16.1278(0.0000)$ \\
\hline Public Expenditure & $9.5844(1.0000)$ & $4.5209(1.0000)$ & \\
\hline
\end{tabular}

Source: Researcher's Computations

In Table 2, the stationarity results indicate that tax and foreign aid and grants are stationary at first differencing, which means that they are integrated at order one I(1). Budget deficit and public expenditure are stationary at second differencing, meaning that they are integrated at order two I(2). Cointegration tests were undertaken to test if the variables have a long-run relationship between them. The Johansen test for cointegration was done where for cointegration to exist, the trace statistic should be greater than the critical values at a $5 \%$ level of significance.

\section{Table 3: Results of Johansen Cointegration Test}

\begin{tabular}{|c|c|c|c|c|c|}
\hline & Hypothesized No. of CE (s) & Eigenvalue & Trace Statistic & Critical Value & Prob. \\
\hline \multirow{2}{*}{$\begin{array}{l}\text { Budget Deficit \& Public } \\
\text { Expenditure }\end{array}$} & None* & 0.7121 & 67.3906 & 20.2618 & 0.0000 \\
\hline & At most 1 & 0.1469 & 7.6267 & 9.1645 & 0.0971 \\
\hline \multirow{2}{*}{$\begin{array}{l}\text { Tax \& Public } \\
\text { Expenditure }\end{array}$} & None* & 0.4578 & 50.7290 & 20.2618 & 0.0000 \\
\hline & At most $1^{*}$ & 0.3733 & 21.9590 & 9.1645 & 0.0001 \\
\hline \multirow{2}{*}{$\begin{array}{l}\text { Budget Deficit \& } \\
\text { Unemployment Rate }\end{array}$} & None & 0.1507 & 13.9976 & 20.2618 & 0.2896 \\
\hline & At most 1 & 0.1204 & 6.1599 & 9.1645 & 0.1787 \\
\hline \multirow{2}{*}{$\begin{array}{l}\text { Budget Deficit \& } \\
\text { Inflation Rate }\end{array}$} & None & 0.1834 & 17.8665 & 20.2618 & 0.1034 \\
\hline & At most 1 & 0.1560 & 8.1415 & 9.1645 & 0.0779 \\
\hline \multirow{2}{*}{$\begin{array}{l}\text { Budget Deficit \& } \\
\text { Foreign Aid and Grants }\end{array}$} & None* & 0.3664 & 23.8262 & 20.2618 & 0.0155 \\
\hline & At most 1 & 0.0393 & 1.9244 & 9.1645 & 0.7927 \\
\hline \multirow{2}{*}{$\begin{array}{l}\text { Tax \& Unemployment } \\
\text { Rate }\end{array}$} & None* & 0.3115 & 24.5437 & 20.2618 & 0.0121 \\
\hline & At most 1 & 0.1289 & 6.6260 & 9.1645 & 0.1476 \\
\hline \multirow[t]{2}{*}{ Tax \& Inflation Rate } & None* & 0.3396 & 28.3674 & 20.2618 & 0.0031 \\
\hline & At most 1 & 0.1614 & 8.4514 & 9.1645 & 0.0682 \\
\hline \multirow{2}{*}{$\begin{array}{l}\text { Tax \& Foreign Aid and } \\
\text { Grants }\end{array}$} & None* & 0.3047 & 27.7818 & 20.2618 & 0.0038 \\
\hline & At most $1^{*}$ & 0.1938 & 10.3415 & 9.1645 & 0.0298 \\
\hline \multirow{2}{*}{$\begin{array}{l}\text { Budget Deficit \& } \\
\text { Economic Growth }\end{array}$} & None* & 0.2833 & 22.8470 & 20.2618 & 0.0216 \\
\hline & At most 1 & 0.1332 & 6.8587 & 9.1645 & 0.1341 \\
\hline \multirow{2}{*}{$\begin{array}{l}\text { Tax \& Economic } \\
\text { Growth }\end{array}$} & None* & 0.3861 & 40.1734 & 20.2618 & 0.0000 \\
\hline & At most $1^{*}$ & 0.2946 & 16.7532 & 9.1645 & 0.0016 \\
\hline
\end{tabular}

* denotes rejection of the null hypothesis at the 0.05 level of significance

Source: Researcher's Computations 
The results in Table 3 indicate that budget deficit and public expenditure are cointegrated since the trace statistics of 67.3906 is greater than the critical value of 20.2618 at a $5 \%$ level of significance. Similarly, there is cointegration between tax and public expenditure since the trace statistics is greater than the critical value at a $5 \%$ level of significance. However, the tax seems to have a stronger cointegration level, which is essentially a stronger long-run relationship with public expenditure compared to the budget deficit with public expenditure, as evidenced by the number of cointegrating equation results in Table 3 . Granger causality tests were undertaken to determine if one variable causes another or simply test one variable's level of prediction against another. As indicated in Table $1 \mathrm{~A}$ in the appendix, there was no Granger causality between the variables at a $5 \%$ level of significance.

\subsection{Model Specification}

\subsubsection{Fiscal Policy Stance, Economic Growth, Macroeconomic Factors, and Public Expenditure}

This paper's key objective was to examine the relationship between fiscal policy stance, economic growth, selected macroeconomic factors, and public expenditure in Kenya. Before the modelling was done, the lag selection was undertaken in order to establish the number of lags in the model, as indicated in Table 2A in the appendix. A VECM model was then used to test the hypothesis. Before running the model, diagnostic tests, which entail; the Johansen cointegration test and the Stationarity test, were conducted to ascertain that the model generates robust results. The data were tested for stationarity, as indicated in Table 2. There was cointegration between fiscal policy stance, economic growth, macroeconomic factors, and public expenditure; hence a VECM model was the most appropriate model to be used. The VECM model is as shown next;

Table 6: VECM Model

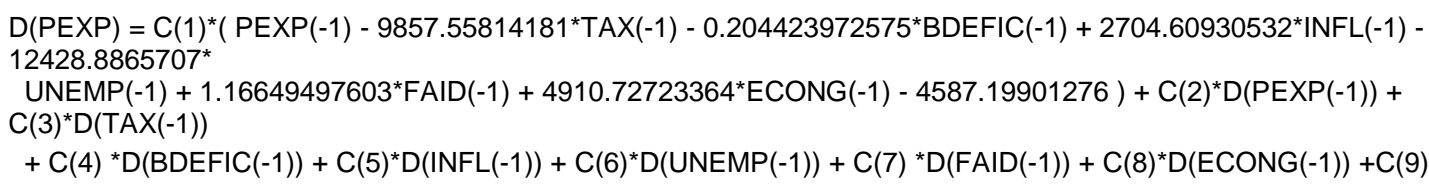

\begin{tabular}{crrrr}
\hline \hline & Coefficient & Std. Error & t-Statistic & Prob. \\
\hline \hline C(1) & 0.321258 & 0.037053 & 8.670243 & 0.0000 \\
C(2) & -0.871875 & 0.204833 & -4.256523 & 0.0001 \\
C(3) & 24205.61 & 25709.10 & 0.941519 & 0.3522 \\
C(4) & -0.496914 & 0.220301 & -2.255617 & 0.0298 \\
C(5) & -682.9195 & 506.7241 & -1.347715 & 0.1855 \\
C(6) & 2527.594 & 3475.739 & 0.727211 & 0.4714 \\
C(7) & 1.662271 & 0.674513 & 2.464400 & 0.0182 \\
C(8) & -503.5120 & 1171.532 & -0.429789 & 0.6697 \\
C(9) & 43966.67 & 5844.424 & 7.522841 & 0.0000 \\
\hline \hline
\end{tabular}


Gatauwa, J. M. (2020). “Does Fiscal Policy Stance affect Public Expenditure: Evidence from Kenya”, International Journal of Public Finance, 5(2), 295-310.

\begin{tabular}{lrll} 
SE of regression & 25450.53 & Akaike info criterion & 23.29422 \\
Sum squared resid & $2.53 \mathrm{E}+10$ & Schwarz criterion & 23.64507 \\
Log-likelihood & -550.0613 & Hannan-Quinn criteria. & 23.42681 \\
F-statistic & 17.54466 & Durbin-Watson stat & 1.853361 \\
Prob(F-statistic) & 0.000000 & & \\
\hline \hline
\end{tabular}

Source: Researcher's Computations

Table 6 shows the effect of fiscal policy stance (a budget deficit), foreign aid \& grants, and the lagged variable of public expenditure on public expenditure as statistically significant as indicated by the $p$-values. At the same time, the $\mathrm{R}^{2}$ is $78.26 \%$, meaning that $78.26 \%$ of the variations in public expenditure can be explained by fiscal policy stance, foreign aid \& grants, and the lagged variable of public expenditure. The $p$-value of $\mathrm{C}(1)$ or the constant is 0.0000 , meaning a long-run causality running from fiscal policy stance and foreign aid \& grants to public expenditure. The f-statistic is 0.000000 , meaning that the model fits the data well. Short-run causality was also tested using the Wald test, as indicated in Table 7.

Table 7: Wald Test

\begin{tabular}{|l|l|l|l|l|}
\hline & Test Statistic & Value & df & Probability \\
\hline Tax on Public expenditure & Chi-square & 0.886458 & 1 & 0.3464 \\
\hline A budget deficit on Public expenditure & Chi-square & 5.087806 & 1 & 0.0241 \\
\hline Inflation Rate on Public expenditure & Chi-square & 1.816335 & 1 & 0.1778 \\
\hline Unemployment Rate on Public expenditure & Chi-square & 0.528835 & 1 & 0.4671 \\
\hline Foreign aid \& grants on Public expenditure & Chi-square & 6.073268 & 1 & 0.0137 \\
\hline Economic growth on Public expenditure & Chi-square & 0.184719 & 1 & 0.6673 \\
\hline
\end{tabular}

Source: Researcher's Computations

As indicated in Table 7, there was no short-run causality running from tax to public expenditure, inflation rate to public expenditure, unemployment rate to public expenditure, and economic growth to public expenditure as indicated by the $p$-value of $0.3464,0.1778,0.4671$, and 0.6673 respectively. However, short-run causality runs from budget deficit to public expenditure and from foreign aid and grants to public expenditure as indicated by the $p$-value of 0.0241 and 0.0137 , respectively. A serial correlation test was done in order to determine if there was any autocorrelation between the variables after running the model, as indicated in Table 8.

\section{Table 8: Serial Correlation}

\begin{tabular}{|l|l|}
\hline \multicolumn{2}{|l|}{ Breusch-Godfrey Serial Correlation LM Test: } \\
\hline F-statistic 0.578581 & Prob. F(1,38) 0.4516 \\
\hline Obs*R-squared 0.719879 & Prob. Chi-Square (1) 0.3962 \\
\hline
\end{tabular}

Source: Researcher's Computations

From Table 8, we accept the null hypothesis that there is no serial correlation in the series residual as indicated by the $p$-value of 0.3962 . A heteroscedasticity test was done in order to determine if there was heteroscedasticity between the variables after running the model, as shown in Table 9. 
Gatauwa, J. M. (2020). “Does Fiscal Policy Stance affect Public Expenditure: Evidence from Kenya”, International Journal of Public Finance, 5(2), 295-310.

Table 9: Heteroscedasticity Test

\begin{tabular}{|l|l|}
\hline Heteroskedasticity Test: Breusch-Pagan-Godfrey \\
\hline F-statistic 1.070221 & Prob. F(1,38) 0.4166 \\
\hline Obs*R-squared 14.98838 & Prob. Chi-Square (14) 0.3789 \\
\hline Scaled explained SS 45.93006 & Prob. Chi-Square (14) 0.0000 \\
\hline
\end{tabular}

Source: Researcher's Computations

As indicated in Table 9, we accept the null hypothesis that states that there is no heteroscedasticity as indicated by the $p$-value of 0.3789 at a $5 \%$ level of significance while the corresponding $\mathrm{R}^{2}$ is 14.98838 .

\subsection{Discussion}

This paper found that the fiscal policy stance (a budget deficit) has a significant negative relationship with public expenditure. These findings are similar to those of Gatauwa et al. (2017) and Beetsma et al. (2008), even though they later found that budget deficits positively correlate with public expenditure. The study findings also indicate that foreign aid and grants significantly affect public expenditure, which concurs with those of Njeru (2003) and even with study findings by Remmer (2004) that foreign aid generates incentives and opportunities for public expenditure growth. On economic growth and public expenditure, Bagdigen \& Cetintas (2003) found no significant relationship between economic growth and public expenditure, which concurs with the study findings. Also, Deskins et al. (2010) had similar findings that public education spending has no significant relationship with the economy's growth. However, Srinivasan (2013) found that public expenditure is affected by economic growth, supporting Wagner's law of increasing state activities. On the inflation rate and public expenditure, Magazzino (2011) found a long-run relationship between inflation and public expenditure growth in Portugal. However, Han \& Mulligan (2008) found a weak relationship between inflation and non-defense public expenditure. Similarly, this study found that there was a weak effect on the inflation rate on public expenditure.

\section{Conclusion}

This paper contributes to the existing literature in a number of ways; firstly, the study provides evidence on the link between fiscal policy stance and public expenditure, considering the limited empirical literature on the study area. Secondly, the study demonstrates that despite fiscal policy stance having a weak link with public expenditure, when macroeconomic factors are incorporated, then the effect on public expenditure is significant. Thirdly, the significant effect of foreign aid and grants on public expenditure in Kenya implies that it is a critical factor in explaining the level of public expenditure. The lagged value of public expenditure has a significant effect on public expenditure, which implies that the previous year's public expenditure is a crucial determinant of the public expenditure amounts in a particular current year. 
Finally, budget deficits have a statistically significant relationship with public expenditure, implying that the fiscal policy stance influences public expenditure levels in a country. The other variables have a weak effect on public expenditure, which means that other variables explain the effects on public expenditure apart from the lagged values of public expenditure, fiscal policy stance (a budget deficit), and foreign aid and grants.

This paper's policy implications are derived from the findings of a weak effect of fiscal policy stance on public expenditure, thus implying that fiscal policy is not effective in controlling the levels of public expenditure. That should inform policymakers on how to utilize fiscal policy to attain fiscal policy goals on redistribution and reallocation of resources, as postulated by Musgrave and Johansen in the theory of fiscal policy. Nevertheless, the fiscal policy stance affects public expenditure indirectly through economic growth and macroeconomic factors in Kenya.

\section{References}

Amanja, D. \& Morrissey, O. (2005). "Fiscal Policy and Economic Growth in Kenya", CREDIT Research Paper No. 05/06.

Bagdigen, M. \& Cetintas, H. (2003). "Causality Between Public Expenditure and Economic Growth: The Turkish Case", MPRA Paper No. 8576, MPRA.

Barro, R. (1991). "Economic Growth in A Cross Section of Countries", Quarterly Journal of Economics, 106, 407-444.

Barro, R. \& Grilli, V. (1994). European Macroeconomics, Basingstoke, Hampshire: Macmillan.

Beetsma, R., Giuliodori, M. \& Klaassen, F. (2008). "The Effects of Public Spending Shocks On Trade Balances and Budget Deficits in the European Union", Journal of the European Economic Association, 6(2-3), 414-423.

Bird, N. \& Kirira, N. (2009). "Government Institutions, Public Expenditure and The Role of Development Partners: Meeting Kenya's Environmental Challenges," Overseas Development Institute Report, ODI.

Bui, D. T. (2020). "Fiscal Sustainability in Developing Asia - New Evidence from Panel Correlated Common Effect Model", Journal of Asian Business and Economic Studies, 27(1), 66-80.

Clark, T. \& Dilnot, A. (2001). "Measuring the UK Fiscal Stance Since the Second World War", The Institute for Fiscal Studies, Briefing Note No. 26.

Deskins, J., Hill, B. \& Ullrich, L. (2010). "Education Spending and State Economic Growth: Are All Dollars Created Equal?" Economic Development Quarterly, 24(1), 45-59. 
Dornbusch, R., Fischer, S. \& Startz, R. (2017). Macroeconomics, $13^{\text {th }}$ Ed, New York: McGraw Hill.

Gatauwa, J. M, Kaijage, E. S., Sifunjo, K. \& Kiriti-Nganga, T. W. (2017). "Fiscal Policy Stance and Public Expenditure in Kenya", The Pan-African Journal of Business and Management, 1(2), 61-80.

Glomm, G. \& Rioja, F. (2006). Fiscal Policy and Long-Run Growth in Brazil, Mimeo, Indiana University.

Han, S. \& Mulligan, B. (2008). "Inflation and the Size of Government", Federal Reserve Bank of St. Louis Review, 90(3), 245-267.

Henrekson, M. (1993). "Wagner's Law: A Spurious Relationship?”, Public Finance, 48(2), 406-415.

Johansen, L. (1965). Public Economics, Amsterdam: North Holland Publishing Co.

Kim, S. (2019). "Fiscal Autonomy and Stabilization: An Empirical Analysis of US State Governments" Journal of Financial Economic Policy, Emerald Publishing Limited, 1757-6385. DOI 10.1108/JFEP-06-2019-0106.

Magazzino, C. (2011). "The Nexus Between Public Expenditure and Inflation in the Mediterranean Countries", MPRA Paper No. 28493, MPRA.

Mosoti, M. (2014). "The Growth of Public Expenditure in Kenya: Exploring the Causes (1980-2012)", Unpublished MA Thesis, University of Nairobi.

Musgrave, R. (1959). The Theory of Public Finance, New York: McGraw-Hill.

Muthui, J., Kosimbei, G., Maingi, J. \& Thuku, G. (2013). "The Impact of Public Expenditure Components on Economic Growth in Kenya 1964-2011", International Journal of Business and Social Science, 4(4), 233-253.

Nafula, N., Kimalu, P., Kiringai, J., Owino, R., Manda, D. \& Karingi, S. (2004). "Budget Mechanisms and Public Expenditure Tracking in Kenya", KIPPRA Discussion Paper No. 37, KIPPRA.

Njeru, J. (2003). "The Impact of Foreign Aid on Public Expenditure: The Case of Kenya", AERC Research Paper No. 135, AERC.

Njuru, S., Ombuki, C., Wawire, N. \& Okeri, S. (2014). "Impact of Government Expenditure on Private Investment in Kenya", Research journali's Journal of Economics, 2(8), 1-19.

Pailwar, V. (2008). Economic Environment of Business, New Delhi: Prentice-Hall of India.

Peacock, A. \& Wiseman, J. (1961). The Growth of Public Expenditure in the United Kingdom, Princeton: Princeton University Press.

Perotti, R. (2007). "Fiscal Policy in Developing Countries: A Framework and Some Questions", World Bank Research Working Paper No. 4365, World Bank. 
Remmer, K. (2004). "Does Foreign Aid Promote the Expansion of Government?" American Journal of Political Science, 48(1), 77-92.

Romer, P. (1990). "Human Capital and Growth: Theory and Evidence", CarnegieRochester Conference Series on Public Policy, 40, 47-57.

Sabir, S. \& Qamar, M. (2019). "Fiscal Policy, Institutions and Growth: Evidence from the Developing Asian Countries", International Journal of Social Economics, 46(6), 822-837.

Sakyi, D. \& Adams, S. (2012). "Democracy, Government Spending and Economic Growth: The Case of Ghana, 1960-2008", Margin-The Journal of Applied Economic Research, 6(3), 361-383.

Sans, I. \& Velazquez, F. (2002). "Determinants of the Composition of Government Expenditure by Functions", European Economy Group Working Paper No.13, ECG.

Semmler, W., Greiner, A., Diallo, B., Rezai, A. \& Rajaram, A. (2007). “Fiscal Policy, Public Expenditure Composition and Growth", World Bank Policy Working Paper No. 4405.

Shonchoy, A. (2010). "What is Happening with the Government Expenditure of Developing Countries - A Panel Data Study", In Proceedings of the German Development Economics Conference, Hannover, Germany.

Srinivasan, P. (2013). "Causality Between Public Expenditure and Economic Growth: The Indian Case", International Journal of Economics and Management, 7(2), 335-347.

Stancik, J. \& Valila, T. (2012). "Changes in the Fiscal Stance and the Composition of Public Spending", Empirical Economics, 43, 199-217.

Tanzi, V. (2006). "Fiscal Policy: When Theory Collides with Reality", CEPS Working Document No. 246, CEPS.

Temple, J. (2003). "The Long-Run Implications of Growth Theories", Journal of Economic Surveys, 17(3), 497-510.

Tsai, P. H. (2014). "State Fiscal Rules and Composition Changes in Public Spending Before the Election", Public Finance Review, 42(1), 58-91.

Wagner, A. (1863). "Grundlegung der Politischen Ökonomie", Available at: http://www.google.com. (accessed on August 2019).

Zikmund, W. (2002). Business Research Methods, $7^{\text {th }}$ Ed. Thomson/South-Western. 
Gatauwa, J. M. (2020). “Does Fiscal Policy Stance affect Public Expenditure: Evidence from Kenya”, International Journal of Public Finance, 5(2), 295-310.

\section{APPENDIX}

Figure 1: Annual Budget Deficits, 1964 - 2015

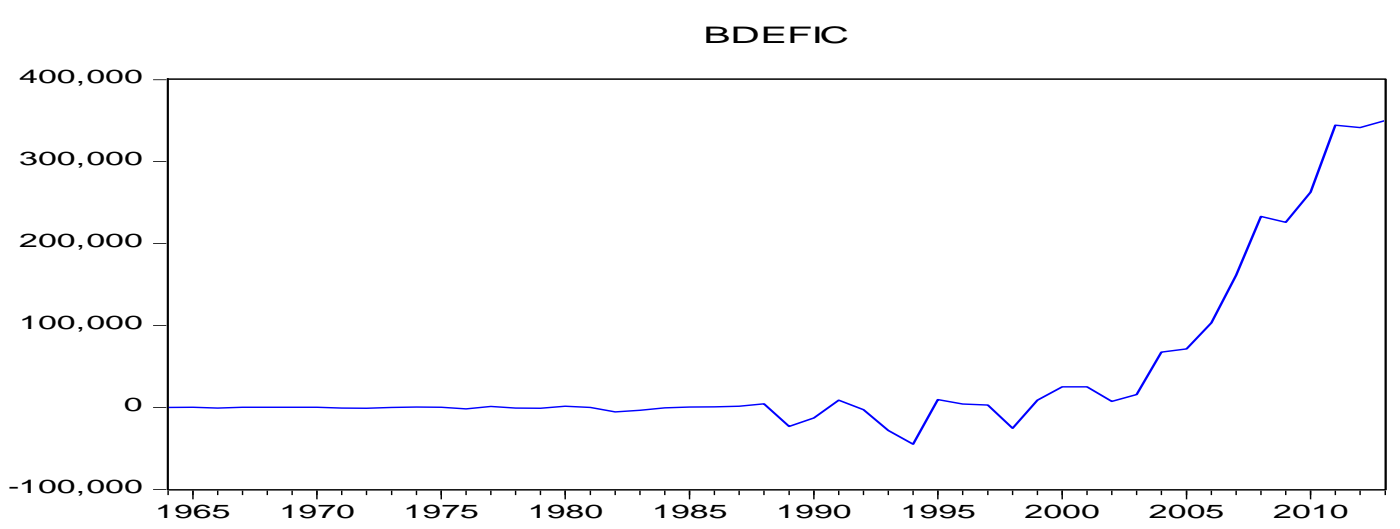

Source: Kenya National Bureau of Statistics Reports

Figure 2: Annual Tax Revenues, 1964 - 2015

TAX

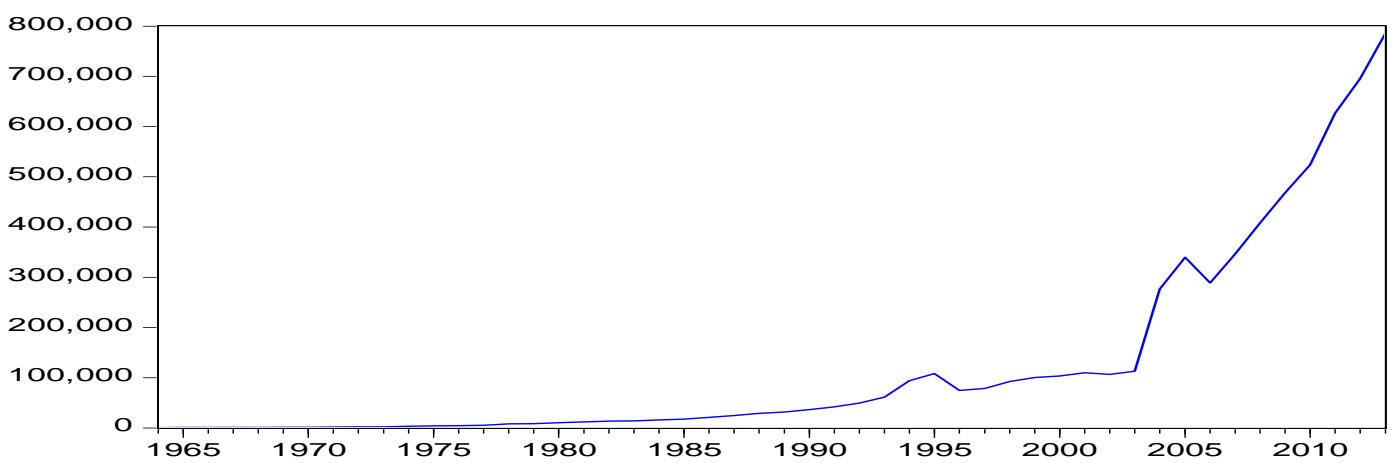

Source: Kenya National Bureau of Statistics Reports

Figure 3: Annual Public Expenditure, 1964 - 2015

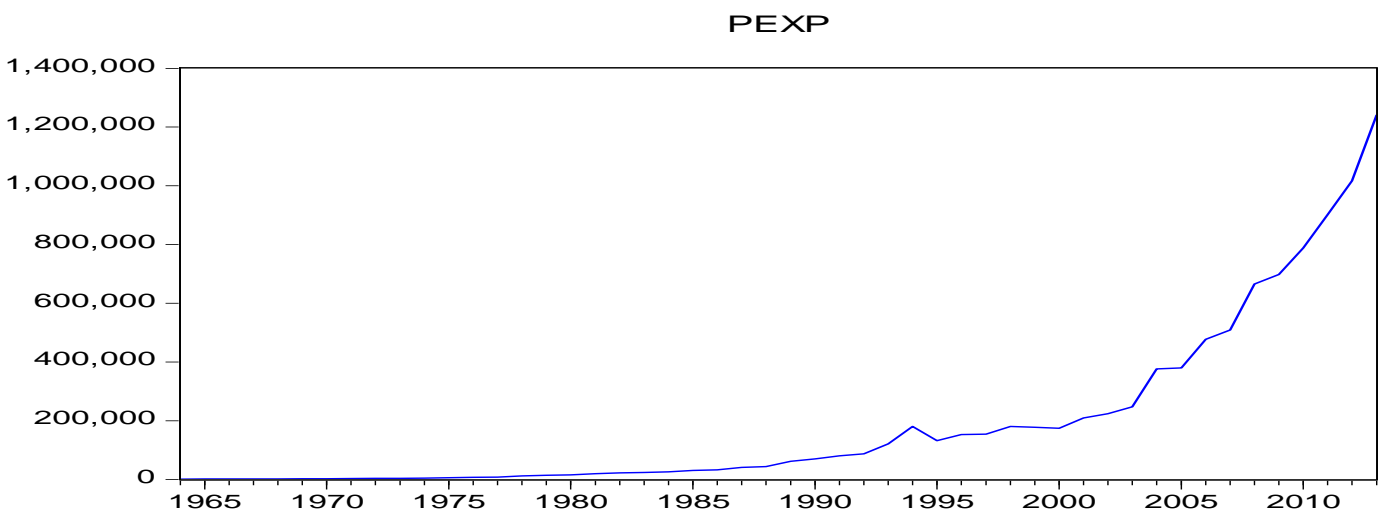

Source: Kenya National Bureau of Statistics Reports 
Gatauwa, J. M. (2020). “Does Fiscal Policy Stance affect Public Expenditure: Evidence from Kenya”, International Journal of Public Finance, 5(2), 295-310.

Table 1A: Results of Granger Causality Tests

\begin{tabular}{|l|l|l|}
\hline Null Hypothesis & f-Statistic & Probability \\
\hline Tax revenue does not Granger cause public expenditure & 0.2904 & 0.7494 \\
\hline Public expenditure does not Granger cause tax revenue & 2.4340 & 0.0997 \\
\hline Budget deficit does not Granger cause tax revenue & 0.4930 & 0.6142 \\
\hline Tax revenue does not Granger cause budget deficit & 1.6651 & 0.2011 \\
\hline Budget deficit does not Granger cause economic growth & 0.2468 & 0.7824 \\
\hline Economic growth does not Granger cause budget deficit & 1.3203 & 0.2777 \\
\hline Tax revenue does not Granger cause economic growth & 3.1838 & 0.0514 \\
\hline Economic growth does not Granger cause tax revenue & 0.3677 & 0.6945 \\
\hline Tax revenue does not Granger cause inflation rate & 0.0103 & 0.9898 \\
\hline Inflation rate does not Granger cause tax revenue & 1.5524 & 0.2234 \\
\hline Budget deficit does not Granger cause inflation rate & 0.7747 & 0.4672 \\
\hline Inflation rate does not Granger cause budget deficit & 0.6156 & 0.5450 \\
\hline Tax revenue does not Granger cause unemployment rate & 0.0311 & 0.9694 \\
\hline Unemployment rate does not Granger cause tax revenue & 0.0905 & 0.9137 \\
\hline Budget deficit does not Granger cause unemployment rate & 0.0366 & 0.9641 \\
\hline Unemployment rate does not Granger cause budget deficit & 0.0233 & 0.9770 \\
\hline Foreign aid \& grants does not Granger cause budget deficit & 1.5967 & 0.2143 \\
\hline Budget deficit does not Granger cause foreign aid \& grants & 0.2880 & 0.7512 \\
\hline
\end{tabular}

Significance level at 5\%

Source: Researcher's Computations

Table 2A: Lag Length Selection

\begin{tabular}{|l|l|l|l|l|l|l|}
\hline Lag & LogL & LR & FPE & AIC & SC & HQ \\
\hline 0 & -1424.823 & NA & $2.56 \mathrm{e}+18$ & 62.25316 & 62.53143 & 62.35741 \\
\hline 1 & -1179.444 & $405.4080^{*}$ & $5.15 \mathrm{e}+14^{*}$ & 53.71497 & $55.94114^{*}$ & $54.54890^{*}$ \\
\hline 2 & -1135.047 & 59.84006 & $7.29 \mathrm{e}+14$ & 53.91508 & 58.08915 & 55.47871 \\
\hline 3 & -1079.330 & 58.13959 & $8.30 \mathrm{e}+14$ & 53.62303 & 59.74500 & 55.91636 \\
\hline 4 & -1003.498 & 56.04972 & $6.81 \mathrm{e}+14$ & $52.45642^{*}$ & 60.52630 & 55.47944 \\
\hline
\end{tabular}

* indicates lag order selected by the criterion

Significance level at $5 \%$

Source: Researcher's Computations 